\title{
Structural analussis of the JBW (Na-J, barrer and white) zeotupe obtained from kaolinite-rich clay
}

\author{
Análisis estructural del zeotipo JBW (Na-J, barrer y white) obtenido a \\ partir de arcilla rica en caolinita
}

Análise estrutural do zeotipo JBW (Na-J, barrer e white) obtido a partir de argila rica em caulinita

Fecha de recepción: 4 de mayo de 2018

Fecha de aprobación: 15 de julio de 2018

\author{
Mario Alberto Macías-López*
Carlos Alberto Ríos-Reyes \\ Oscar Mauricio Castellanos-Alarcón ${ }^{* * *}$
}

\section{Abstract}

The JBW zeolite was prepared from hydrogels under hydrothermal conditions by alkaline reaction, using $\mathrm{NaOH}$ as activating agent. The synthetic zeotype was studied by analytical techniques such as X-ray powder diffraction, scanning electron microscopy, Fourier transformed infrared spectroscopy and solid-state ${ }^{29} \mathrm{Si}$ and ${ }^{27} \mathrm{Al}$ Magic angle spinning nuclear magnetic resonance. Crystallographic data revealed that the JBW structure can be described by the orthorhombic space group Pna $2_{1}$, with unit cell parameters $a=16.409(2) \AA, b=14.966(2) \AA$ and $c=5.2154(5) \AA$.

Keywords: hydrogels; JBW structure; orthorhombic; space group; unit cell; zeotype.

\section{Resumen}

La zeolita JBW fue preparada a partir de hidrogeles en condiciones hidrotérmicas por reacción alcalina, usando $\mathrm{NaOH}$ como agente activante. El zeotipo sintético se estudió por técnicas analíticas como difracción de rayos X en polvo, microscopía electrónica de barrido, espectroscopia infrarroja por transformada de Fourier y resonancia magnética nuclear de giro con ángulo mágico en estado sólido de ${ }^{29} \mathrm{Si}{ }^{27} \mathrm{Al}$. Los datos cristalográficos revelan que la estructura JBW puede ser descrita por el grupo espacial ortorrómbico $P n a 2_{1}$, con parámetros de celda unidad $a=16.409(2) \AA, b=14.966(2) \AA \mathrm{y} c=5.2154(5) \AA$.

Palabras clave: celda unidad; estructura JBW; grupo espacial; hidrogeles; ortorrómbico; zeotipo.

* Ph. D. Universidad Industrial de Santander (Bucaramanga-Santander, Colombia).

** Ph. D. Universidad Industrial de Santander (Bucaramanga-Santander, Colombia). carios@uis.edu.co.

*** Ph. D. (c), Universidad de Pamplona (Pamplona-Norte de Santander, Colombia). 


\section{Resumo}

A zeolita JBW foi preparada a partir de hidrogeles em condições hidrotérmicas por reação alcalina, usando $\mathrm{NaOH}$ como agente ativante. $\mathrm{O}$ zeotipo sintético estudou-se por técnicas analíticas como difração de raios $\mathrm{X}$ em pó, microscopia eletrônica de varredura, espectroscopia infravermelha por transformada de Fourier e ressonância magnética nuclear de giro com ângulo mágico em estado sólido de ${ }^{29} \mathrm{Si} \mathrm{e}^{27} \mathrm{Al}$. Os dados cristalográficos revelam que a estrutura JBW pode ser descrita pelo grupo espacial ortorrômbico $P n a 2_{1}$, com parâmetros de célula unidade $a=16.409(2) \AA, b=14.966(2) \AA$ e $c=5.2154(5) \AA$.

Palavras chave: célula unidade; estrutura JBW; grupo espacial; hidrogeles; ortorrômbico; zeotipo.

\section{Cómo citar este artículo:}

M. A. Macías-López, C. A. Ríos-Reyes, and O. M. Castellanos-Alarcón, "Structural analysis of the JBW (Na-J, barrer and white) zeotype obtained from kaolinite-rich clay," Revista Facultad de Ingenieria, vol. 27 (49), pp. 23-33, Sep. 2018. 


\section{INTRODUCTION}

Zeolites represent a very important family of crystalline microporous aluminosilicates that allow the adsorption of water and other cations. They are characterized by a three- dimensional (3D) structure, with $\left[\mathrm{SiO}_{4}\right]^{4-}$ and $\left[\mathrm{AlO}_{4}\right]^{5-}$ tetrahedra sharing corners that form cavities occupied by large ions and water molecules with great freedom of movement, which promote ion exchange and reversible dehydration. Zeotypes can be distinguished by their $\mathrm{Si} / \mathrm{Al}$ ratio and the 3D cages types. Several low-silica zeotypes with $\mathrm{Si} / \mathrm{Al}$ ratio of 1:1, such as zeolite Linde Type A (LTA), sodalite (SOD) and cancrinite (CAN), can be obtained from kaolin without any additional $\mathrm{SiO}_{2}$ source [15]. Selim and Maksod [6] reported the formation of zeolite X (FAU) and zeolite P (GIS) from kaolin using an additional $\mathrm{SiO}_{2}$ source. Moreover, higher $\mathrm{Si} / \mathrm{Al}$ ratio zeolites as mordenite, ZSM-5 and $\mathrm{NaY}$ can be synthesized from kaolin and additional $\mathrm{SiO}_{2}$ source as raw materials [5-10]. Healey et al. [7] synthetized a pure JBW framework under hydrothermal conditions. The JBW structure, which is one of the least investigated zeolites, has the general formula $\left(\mathrm{Na}_{3} \mathrm{H}_{2} \mathrm{O}\right)\left(\mathrm{Si}_{3} \mathrm{Al}_{3} \mathrm{O}_{12}\right)$ [11]. The Structure Commission of the International Zeolite Association assigned the framework-type code (FTC) to the JBW structure, which is derived from the name of the type material Na-J and the initials of the author's names, Barrer and White [12], who were the pioneers in preparing this zeotype. Subsequent work referred it inappropriately as "nepheline hydrate I", due to its similarity in chemical composition with an anhydrous nepheline, although its crystalline structure is unrelated to it. Fig. 1 shows the JBW structure according to Baerlocher and McCusker [11]; the structure of the JBW framework is shown in the upper part. According to Heller-Kallai and Lapides [2], the JBW framework can be described by a zigzag chain -bold in the left middle part- running parallel to $a$-or using the saw chain running parallel to $b$ (lower part)-. The repeated distance along the zigzag chain is about $5.2 \AA$. The two-dimensional (2D) Periodic Building Unit (PerBU) is obtained when the zigzag chains are connected along $c$ into a layer of 6-ring (fused) chairs capped with additional zigzag chains, as shown in the left middle part. An alternative (one-dimensional) PerBU is obtained when 6-ring chairs are 2-fold connected along, forming a cylinder, as depicted in the right middle part. The cylinder wall consists of 8-rings (fused). Hansen and Fälth [13] solved the crystalline structure of the JBW structure (with the exception of a full description of the water molecules), which can be described as orthorhombic, crystallizing in the Pna2 space group, and with unit cell parameters $a=14.426(1)$ $\AA, b=15.014(5) \AA, c=5.224(5) \AA$. They synthetized the JBW structure under hydrothermal conditions at $200{ }^{\circ} \mathrm{C}$ from a sodium aluminosilicate glass in sodium hydroxide solution, although reaction products such as "nepheline hydrate", analcime and cancrinite were formed [13]. Moreover, in the past several years, numerous studies have assessed the JBW structure [12-16]. Healey and co-workers [7-8] prepared pure aluminosilicate JBW by hydrothermal reaction of kaolin in alkaline solutions, using $\mathrm{NaOH}$ and $\mathrm{KOH}$ as activating agents at $225^{\circ} \mathrm{C}$, and the $\mathrm{Na} / \mathrm{Rb}-\mathrm{AlGe}-$ JBW structure from a $\mathrm{Na}$ and $\mathrm{Rb}$-containing reagent at $225^{\circ} \mathrm{C}$. Shimizu and Hamada [17] obtained large crystals of the JBW framework and other zeotypes using a ceramic tube as aluminosilicate source through a bulk material dissolution technique. Tripathi and Parise [18] synthesized aluminogermanate analogues of the JBW structure (Na-AlGe-JBW structure) at $140{ }^{\circ} \mathrm{C}$ from a reactant mixture containing tetramethyl ammonium hydroxide (TMAOH). Lin et al. [14] studied the synthesis of the SOD, CAN and JBW structures under hydrothermal conditions at 200 ${ }^{\circ} \mathrm{C}$, using metakaolinite as starting material. Ríos' [15] experiments focused on the synthesis of a JBW type structure using metakaolinite and precipitated $\mathrm{SiO}_{2}$ as starting materials. In addition, Ríos et al. [19] synthesized several kaolinite-based zeotypes, including a nearly pure JBW-type structure obtained under hydrothermal conditions at $200{ }^{\circ} \mathrm{C}$, using $\mathrm{NaOH}$ as activating agent and triethylamine (TEA) as a structure-directing agent (SDA). The synthesis of JBW-type zeolites under alkaline solutions with aerosil and aluminium triisopropoxide as starting materials, $\mathrm{NaOH}$ as activating agent, and phenol as an organic solvent was reported for the first time by Wei et al. [20]. The JBW-type structure is unusual because its near parts are separated by what is effectively a layer of the cristabolite structure containing non-hydrated cations [13]. According to Weller [21], the existence of this semi-condensed block helps stabilizing higher $\mathrm{Al}$ contents, and the JBW framework is invariably found for a Si/Al ratio of 1:1. The JBW-type structure represents a true hybrid-layered oxide/zeolite structure with alternating channels and condensed non-hydrated oxide blocks [21]. This material, obviously, has structural relationships with pillared clays [22] and the layered complex metal oxides of the $\mathrm{CsNbTi}_{2} \mathrm{O}_{7}$ type [23]. The JBW framework has the advantage of asymmetric pore with dimension $4.8 \times 3.8 \AA$ compared 
with $4.1 \times 4.1 \AA$ for LTA and $7.4 \times 7.4 \AA$ for FAU zeolites. This asymmetric pore may play an important role as a selective molecular sieve and also in the adsorption behavior [6]. In this work, we characterized the kaolinbased JBW framework obtained from hydrogels under hydrothermal conditions by alkaline reaction, using $\mathrm{NaOH}$ as activating agent.

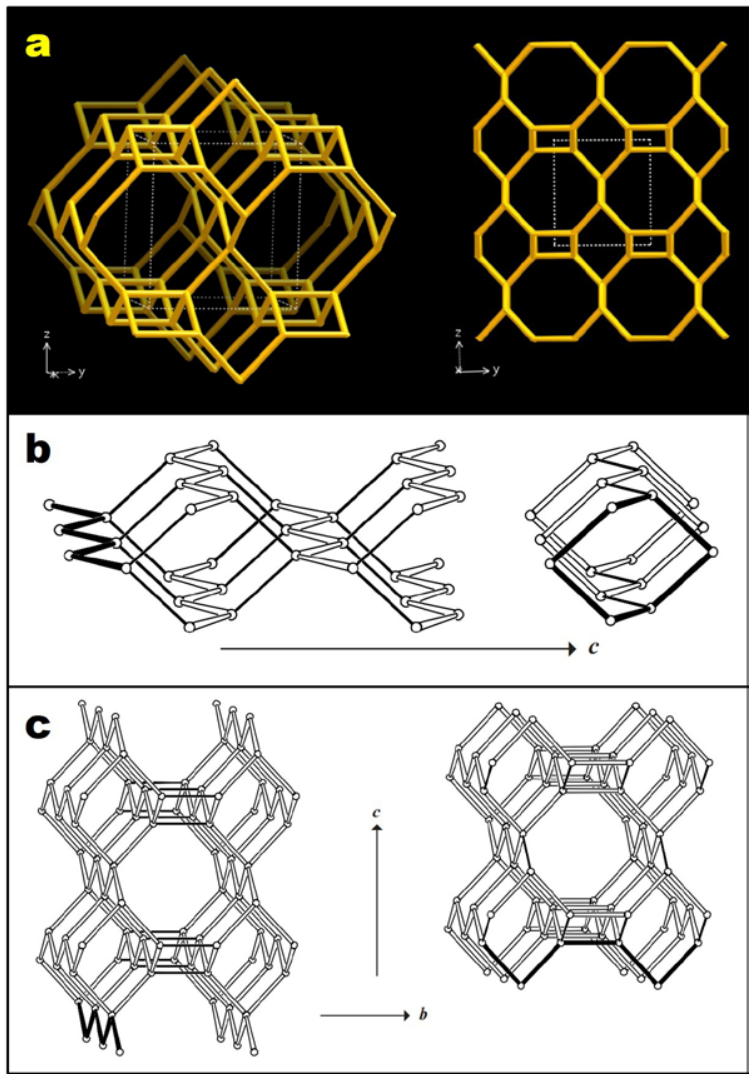

Fig. 1. (a) Structure of the JBW framework viewed along [100] (left) and projected along [100] (right).

(b) PerBU of the JBW structure viewed along $a$, constructed using the zigzag chain. (c) Connection mode of the JBW structure viewed along $a$. Adapted and modified after Baerlocher and McCusker [11].

\section{EXPERIMENTAL}

\section{A. Synthesis of kaolin-based JBW framework and associated phases}

Ríos [15] performed the synthesis of zeotypes, including the JBW framework, using the following procedure: A calculated amount of sodium hydroxide $(\mathrm{NaOH})$ pellets was dissolved by stirring in distilled water in $150-250 \mathrm{ml}$ beakers to prepare $1.33 \mathrm{M}$ and
3.99M NaOH solutions. Then, kaolin was added to the alkaline solutions under stirring conditions until it dissolved completely, to homogenize a reaction hydrogel with a specific molar composition. The influence of calculated amounts of structure-directing agent (SDA) in the reactant mixture was evaluated to obtain several zeotypes. The resulting hydrogels were then transferred to $65 \mathrm{ml}$ polytetrafluoroethylene (PTFE) vessels (Cowie Technology Ltd) and 20 $\mathrm{ml}$ stainless steel autoclaves, which were heated in an oven under static conditions at 100 and $200{ }^{\circ} \mathrm{C}$, respectively, at several reaction times. Subsequently, the vessels and autoclaves were removed from the oven and quenched in cold water to room temperature. The $\mathrm{pH}$ of hydrogels before and after hydrothermal synthesis was measured. The synthesis products were recovered by filtration, washed with water and dried at $80{ }^{\circ} \mathrm{C}$ overnight.

\section{B. Characterization of the JBW framework and associated phases}

The crystalline phases of the untreated kaolin and assynthesized products were identified by X-ray powder diffraction (XRPD) and recorded in a Philips PW1710 powder diffractometer, using $\mathrm{Cu}-\mathrm{K} \alpha$ radiation at $40 \mathrm{kV}$ and $40 \mathrm{~mA}$. The samples were scanned in the $2 \theta$ interval $3-50^{\circ}$. Qualitative phase analysis was conducted using the Joint Committee of Powder Diffraction Standards (JCPDS) database and the Crystallographica SearchMatch software. Data analysis was performed by the Rietveld method using the Jana-2006 software [24]. Scanning electron microscopy (SEM) was performed on a ZEISS EVO50, under the following analytical conditions: I probe $1 \mathrm{nA}, \mathrm{EHT}=20.00 \mathrm{kV}$, beam current of $100 \mu \mathrm{A}$, Signal A=SE1, WD=8.0 mm. Structural characterization was conducted by Fourier transform infrared (FT-IR) spectroscopy with a Mattson Genesis II FT-IR spectrometer for wave number range of 4000$400 \mathrm{~cm}^{-1}$. However, we discuss only the $1200-400 \mathrm{~cm}^{-1}$ region, which showed remarkable changes.

${ }^{29} \mathrm{Si}$ and ${ }^{27} \mathrm{Al}$ magic angle spinning nuclear magnetic resonance (MAS-NMR) spectra were obtained on a Varian Unity INOVA spectrometer. ${ }^{29} \mathrm{Si}$ MASNMR spectra were recorded at $59.6 \mathrm{MHz}$ using 30 $\mu$ s acquisition time; $120 \mathrm{~s}$ repetition time; $5040 \mathrm{~Hz}$ spinning rate; $90.0^{\circ}$ pulse angle (DP). ${ }^{27} \mathrm{Al}$ MASNMR spectra were recorded at $78.1 \mathrm{MHz}$ using 10 $\mu$ s acquisition time; $0.5 \mathrm{~s}$ recycle time; $14000 \mathrm{~Hz}$ spinning rate; $18.9^{\circ}$ pulse angle (DP). The chemical 
shifts for ${ }^{29} \mathrm{Si}$ and ${ }^{27} \mathrm{Al}$, respectively, were referenced to tetramethylsilane (TMS) and $1 \mathrm{M} \mathrm{AlCl}_{3}$ aqueous solution.

\section{RESULTS AND DISCUSSION}

The characteristic morphology of the JBW zeotype crystals (long prismatic lath-like with pseudohexagonal
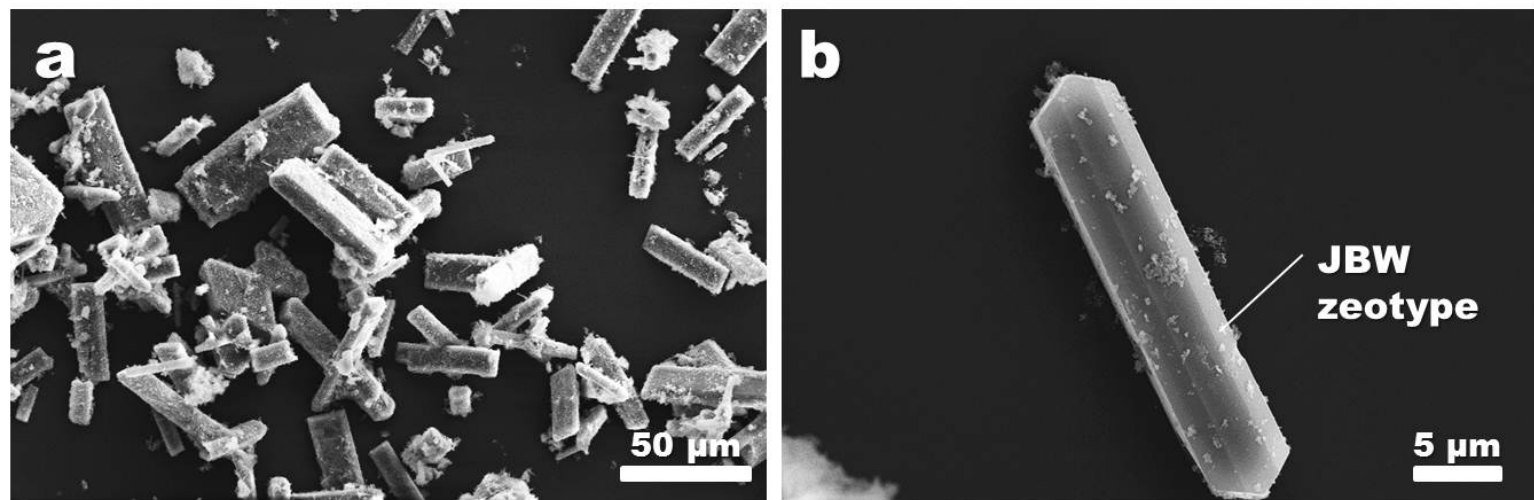

Fig. 2. SEM micrographs of the JBW zeotype crystals obtained after hydrothermal reaction of kaolin in $3.99 \mathrm{M}$ $\mathrm{NaOH}$ solutions at $200^{\circ} \mathrm{C}$ after $168 \mathrm{~h}$.

Fig. 3 illustrates the XRPD patterns of the raw kaolin and the reaction products obtained after hydrothermal transformation of kaolin in $3.99 \mathrm{M} \mathrm{NaOH}$ solutions at $200{ }^{\circ} \mathrm{C}$ for several reaction times. The transformation of kaolinite can be revealed by the formation of the JBW zeotype (with higher intensity peaks) with minor amounts of SOD and CAN, which is in agreement with Lin et al. [14], who concluded that the activation cross sections) was observed in the SEM micrographs (Fig. 2). Wei et al. [20] reported similar morphologies in the JBW-type zeolite obtained by phenol solvothermal synthesis. However, Hegazy et al. [25], using kaolin as starting material in the hydrothermal reaction, obtained JBW crystals with a cylindrical shape, developing spherical agglomerates. at higher temperature promotes the formation of the JBW zeotype. The reaction route allows concluding that the raw kaolin was quickly dissolved giving rise to the formation of several zeotypes, increasing the JBWtype zeolite crystallinity as temperature increased. However, the crystallinity of SOD and CAN showed a constant behavior.

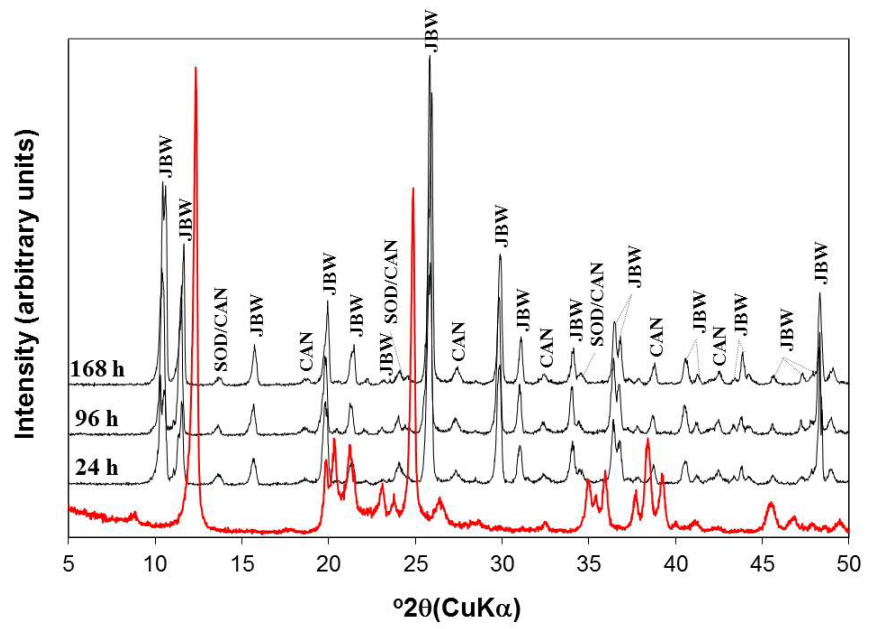

Fig. 3. XRPD patterns of the JBW-type structure obtained after treatment of kaolin (red line) in $3.99 \mathrm{M} \mathrm{NaOH}$ solutions at $200{ }^{\circ} \mathrm{C}$ for several reaction times. 
To characterize the obtained JBW-type zeolite, we performed a careful analysis using the Rietveld method. As we mentioned above, the structure of this compound was originally described using an orthorhombic symmetry with cell parameters $a=15.157 \AA, b=8.218 \AA$ and $c=5.222 \AA$ and space group $P m n 2_{1}$ [26]. In this sense, this model was used as a first approximation to explain the measured pattern that led to a failed result. Following the search for reported JBW-type structures, doubling the $b$ parameter was considered according to Hansen and Fälth [13]. The next refinements considered a double cell in [010] direction. However, in this case, the refined $b$ parameter converged in a different value, far from a simple double parameter. The results led us to consider the model proposed by Healey et al. [7], which was taken as a starting approximation to the true structure (Fig. 4). The refinements using this model allowed us to confirm that the JBW-type structure obtained by the synthesis method used in this work crystallizes in an orthorhombic system with cell parameters $a=16.409(2) \AA, b=14.966(2) \AA$ and $c=5.2154(5) \AA$ and most probable space group
Pna $2_{1}$, with agreement factors $\mathrm{R}_{\mathrm{p}}=7.18, \mathrm{R}_{\mathrm{wp}}=10.05$ and $\chi^{2}=1.4$. These values are close to the originals reported by Healey et al. [7]: $a=16.2906(2) \AA, b=15.0494(2)$ $\AA$ and $c=5.17904(6) \AA$. A comparison of the cell volumes, $\quad V_{\text {our }}=1280.8(2)$ and $V_{\text {Healey }}=1269.71(2)$, suggests an increment in the water molecules contained in the structure. This consideration allows imagining a probable $\mathrm{Na}_{2} \mathrm{~K}\left[\mathrm{Al}_{3} \mathrm{Si}_{3} \mathrm{O}_{12}\right] \cdot x \mathrm{H}_{2} \mathrm{O}$ formula for the synthesized zeolite with $x \sim 2$. A comparison of the unit cell parameters calculated for several JBW zeotypes is given in Table 1, where a correlation with water content can be observed. Considering the similarities with the literature, a sodium-potassium chemical composition is not a surprise considering that the kaolinite precursor was in fact a natural mixture with other phases such illite and muscovite. However, the X-ray diffraction data did not allow us to confirm such assumption, thus, our interpretation relies on the excellent agreement with the structure calculated by Healey et al. [7] using neutron diffraction. This stoichiometry implies that two of three cation sites should be occupied by $\mathrm{Na}$ ions, with $\mathrm{K}$ ions situated on a distinct site (Fig. 4).

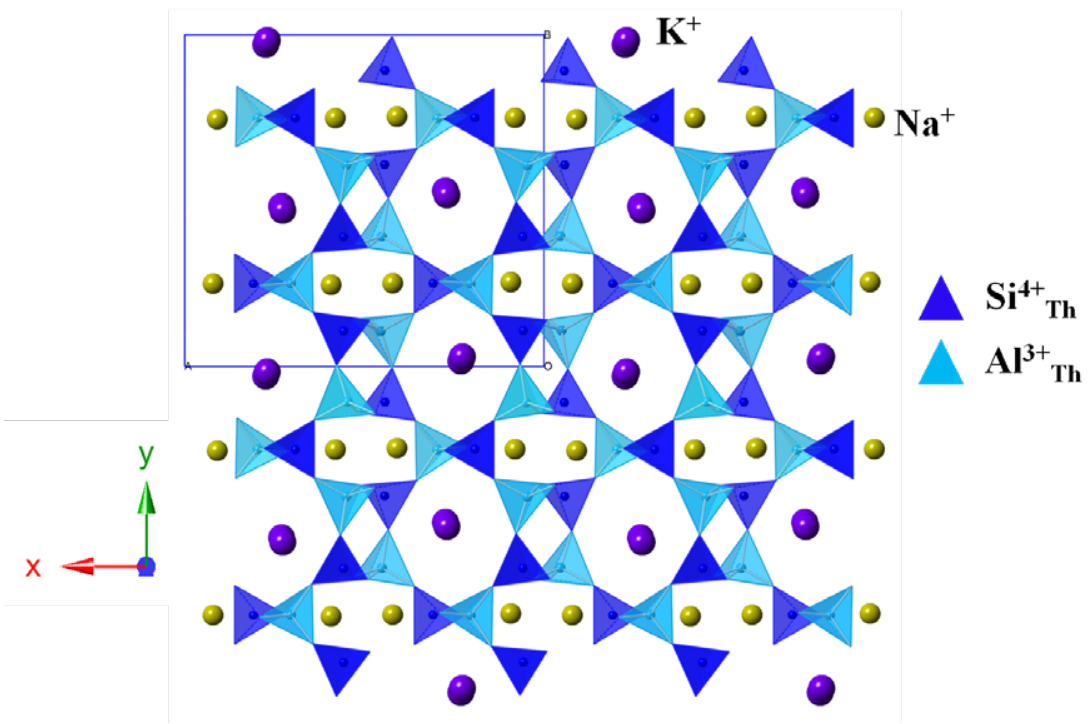

Fig. 4. Structural model used to refine the JBW-zeolite (after Healey et al. [7]). Space group $P n a 2_{1}, a=16.409(2) \AA$, $b=14.966(2) \AA$ and $c=5.2154(5) \AA$. 


\section{TABLe 1}

UNIT CELL PARAMETERS CALCULATED FOR DIFFERENT JBW ZEOTYPES

\begin{tabular}{|c|c|c|c|c|c|c|}
\hline Composition & $\begin{array}{l}\text { Space } \\
\text { group }\end{array}$ & $a(\AA)$ & $b(\AA)$ & $c(\AA)$ & $V\left(\AA^{3}\right)$ & Reference \\
\hline $\mathrm{Na}_{3} \mathrm{Al}_{3} \mathrm{Si}_{3} \mathrm{O}_{12} \cdot 2 \mathrm{H}_{2} \mathrm{O}$ & $P b n 2_{1}$ & $16.321(3)$ & $15.157(8)$ & $5.196(2)$ & 1285.4 & $\begin{array}{l}\text { Ragimov et } \\
\text { al. [27] }\end{array}$ \\
\hline $\mathrm{Na}_{3} \mathrm{Al}_{3} \mathrm{Si}_{3} \mathrm{O}_{12} \cdot 2 \mathrm{H} 2 \mathrm{O}$ & Pna $_{1}$ & $16.426(1)$ & $15.014(1)$ & $5.2235(5)$ & 1288.2 & $\begin{array}{c}\text { Hansen and } \\
\text { Fälth [13] }\end{array}$ \\
\hline $\mathrm{Na}_{2} \mathrm{~K}\left[\mathrm{Al}_{3} \mathrm{Si}_{3} \mathrm{O}_{12}\right] \cdot 0.5 \mathrm{H}_{2} \mathrm{O}$ & $P n a 2_{1}$ & $16.2906(2)$ & $15.0494(2)$ & $5.17904(6)$ & 1269.7 & $\begin{array}{c}\text { Healey et al. } \\
{[8]}\end{array}$ \\
\hline $\mathrm{Na}_{2} \mathrm{~K}\left[\mathrm{Al}_{3} \mathrm{Si}_{3} \mathrm{O}_{12}\right] \cdot x \mathrm{H}_{2} \mathrm{O}$ & $\operatorname{Pna}_{1}$ & $16.409(2)$ & $14.966(2)$ & $5.2154(5)$ & 1280.8 & This work \\
\hline
\end{tabular}

Fig. 5 shows the FT-IR spectra of the raw kaolin and the reaction products obtained after hydrothermal transformation of kaolin in $3.99 \mathrm{M} \mathrm{NaOH}$ solutions at $200{ }^{\circ} \mathrm{C}$ for several reaction times. The characteristic vibration bands $\left(\mathrm{OH}\right.$-stretching at 3687 and $3619 \mathrm{~cm}^{-}$ 1 , the surface $\mathrm{OH}$ bending at 1819,1034 and $942 \mathrm{~cm}^{-}$ ${ }^{1}$, the inner $\mathrm{OH}$ bending at $916 \mathrm{~cm}^{-1}$, and the bands at 801,762 and $696 \mathrm{~cm}^{-1}$ ) of the starting raw material (kaolin) disappeared with reaction time. In general, these bands progressively disappeared and changed in intensity and position at lower wavenumbers, which reveal that there are more $\mathrm{Al}$ substitution in the tetrahedral sites with $\mathrm{NaOH}$ acting as a structure modifier, as reported in previous studies [28-30]. The vibration bands of the synthesis products at low temperature show the asymmetric and symmetric vibration bands characteristic of a mixture of SOD and CAN in the region located between 1200 and $400 \mathrm{~cm}^{-1}$. Barnes et al. [31] summarized the reported assignments of vibration bands for SOD and CAN in this range. Simultaneously to the disappearance of the vibrations bands of the kaolin, typical zeolite bands appeared on the spectra, including the asymmetric and symmetric Al-O stretch vibrations located in the regions of $1250-950 \mathrm{~cm}^{-1}$ and $770-660$ $\mathrm{cm}^{-1}$, respectively. A single vibration band at around
$960-965 \mathrm{~cm}^{-1}$ can be attributed to the presence of CAN. The asymmetric stretch vibration of the Si-OAl linkage in the SOD consists of a single band at $980 \mathrm{~cm}^{-1}$, which split into four bands at 1110, 1050, 1020 , and $960 \mathrm{~cm}^{-1}$ assigned to CAN as suggested by Barnes et al. [31]. However, only the bands at 949 and $953 \mathrm{~cm}^{-1}$, assigned to SOD and CAN, respectively, are reported in this study. A weak vibration band at $754-756 \mathrm{~cm}^{-1}$ can be attributed to the presence of CAN. Several bands in the region between 760 and $650 \mathrm{~cm}^{-1}$ revealed a mixture of SOD and CAN in the reaction products. Breck [32] attributed the vibration bands in the region between 650 and $500 \mathrm{~cm}^{-1}$ to the presence of double rings (D4R and D6R) in the zeotype frameworks. In this region, the vibration bands at 619-621, 594, 554 and $507 \mathrm{~cm}^{-1}$ can be attributed to the presence of six-rings of the dehydrated region and eight-rings of the hydrated section of the JBW zeolite. The vibration bands in the region between 500 and $420 \mathrm{~cm}^{-1}$ were assigned to internal tetrahedron vibrations of $\mathrm{Si}-\mathrm{O}$ and $\mathrm{Al}-\mathrm{O}$ in the as-synthetized zeotypes. The range of 800-400 $\mathrm{cm}^{-1}$, which has been considered as the 'fingerprint' region for SOD and CAN in previous studies [29, 31], also reveals the presence of the JBW zeolite. 


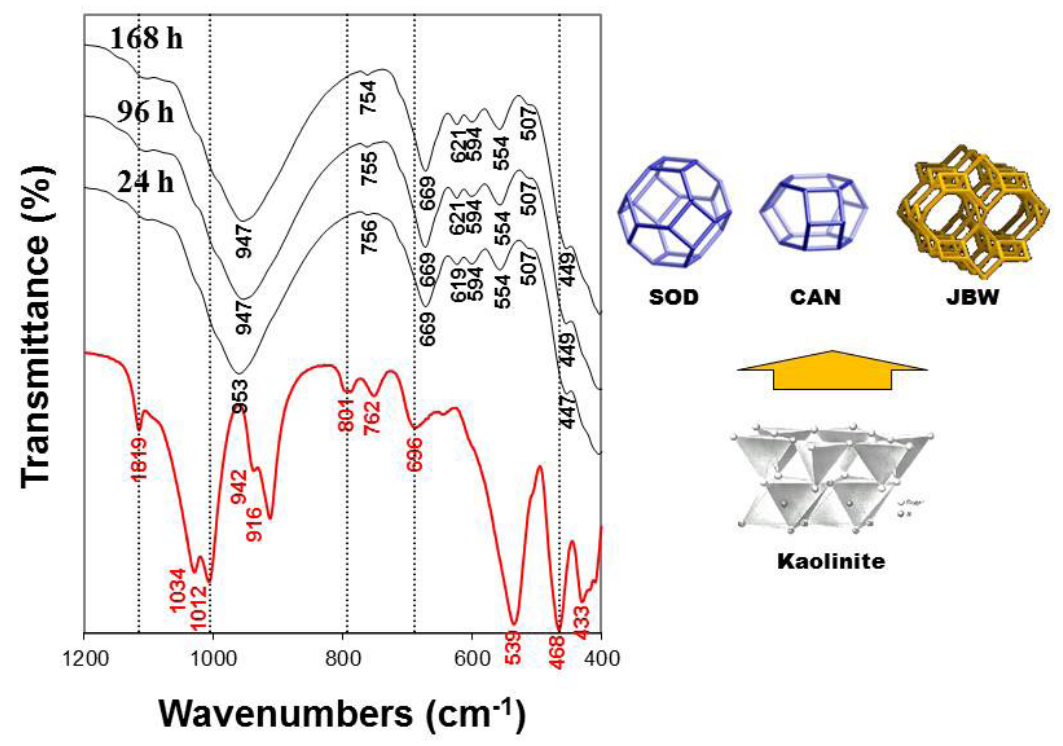

Fig. 5. FT-IR spectra of the JBW-type structure obtained after treatment of kaolin (red line) in 3.99 NaOH solutions at $200{ }^{\circ} \mathrm{C}$ during several reaction times. Kaolinite structure after Klein and Hurlbut [33]. JBW structure and sodalite

(SOD) and cancrinite (CAN) cages after Baerlocher and McCusker [11].

Si-atoms in zeolite frameworks are generally coordinated to four $\mathrm{O}$-atoms in $\mathrm{Q}^{\mathrm{n}}$ tetrahedrons, resulting in a five chemical environment of Si-atoms (Fig. 6a), which can be named as $\mathrm{Si}(\mathrm{nAl})$ units. The $\mathrm{Q}^{\mathrm{n}}$ notation describes the substitution pattern around a specific $\mathrm{Si}$-atom, Q represents a $\mathrm{Si}$ atom surrounded by four O-atoms, and n, the number of Al-atoms in the second sphere of coordination or connectivity [34-35]. According to Cestari et al. [36], in these structures the
Si- and Al-atoms are tetrahedrally coordinated with each other through shared oxygen atoms. ${ }^{27} \mathrm{Al}$ is a spin $5 / 2$ nucleus, therefore, quadrupolar, and is a high sensitivity nucleus that yields broad lines over a wide chemical shift range [34]. As a result, the signal width increases with the asymmetry of the environment, with somewhat broad lines in symmetrical environments (Fig. 6b) but very broad lines in asymmetric ones.

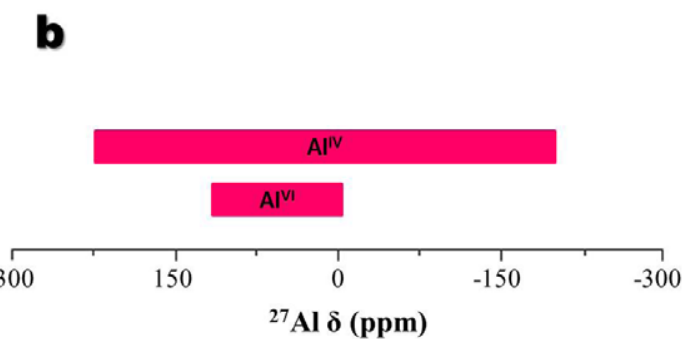

Fig. 6. Chemical shift ranges for (a) Si(nAl) chemical environment of Si-atoms by ${ }^{29} \mathrm{Si} \mathrm{NMR}$ after Mafra et al. [35], and (b) ${ }^{27} \mathrm{Al}$ NMR after [37].

Fig. 7 illustrates the ${ }^{29} \mathrm{Si}$ and ${ }^{27} \mathrm{Al} \mathrm{NMR}$ spectra of the JBW zeotype. The ${ }^{29} \mathrm{Si}$ NMR spectrum (left), which allows investigating the chemical environment of Si-atoms in the JBW structure, revealed two $\mathrm{Si}$ environments, with signals at -85.8 and $-87.9 \mathrm{ppm}$. Similar results have been reported by other authors [7-
$8,14]$ to confirm the characteristic framework of the JBW-type structure. They attributed the smallest of the two peaks (at $-85.8 \mathrm{ppm}$ ) to $\mathrm{Si}(1)$, whereas other two chemically similar $\mathrm{Si}$-atoms, $\mathrm{Si}(2)$ and $\mathrm{Si}(3)$, lead to the largest of the two peaks (at $-87.9 \mathrm{ppm}$ ). However, the weak signal at $-85.8 \mathrm{ppm}$ can be attributed to the 
contribution of $\mathrm{Q}^{4}(4 \mathrm{Al})$ sites of SOD $+\mathrm{CAN}$. The ${ }^{27} \mathrm{Al}$ NMR spectrum (right) of the JBW framework showed a single resonance at $56.8 \mathrm{ppm}$, which was assigned to a 4-coordinated Al local environment in the JBW-type structure.
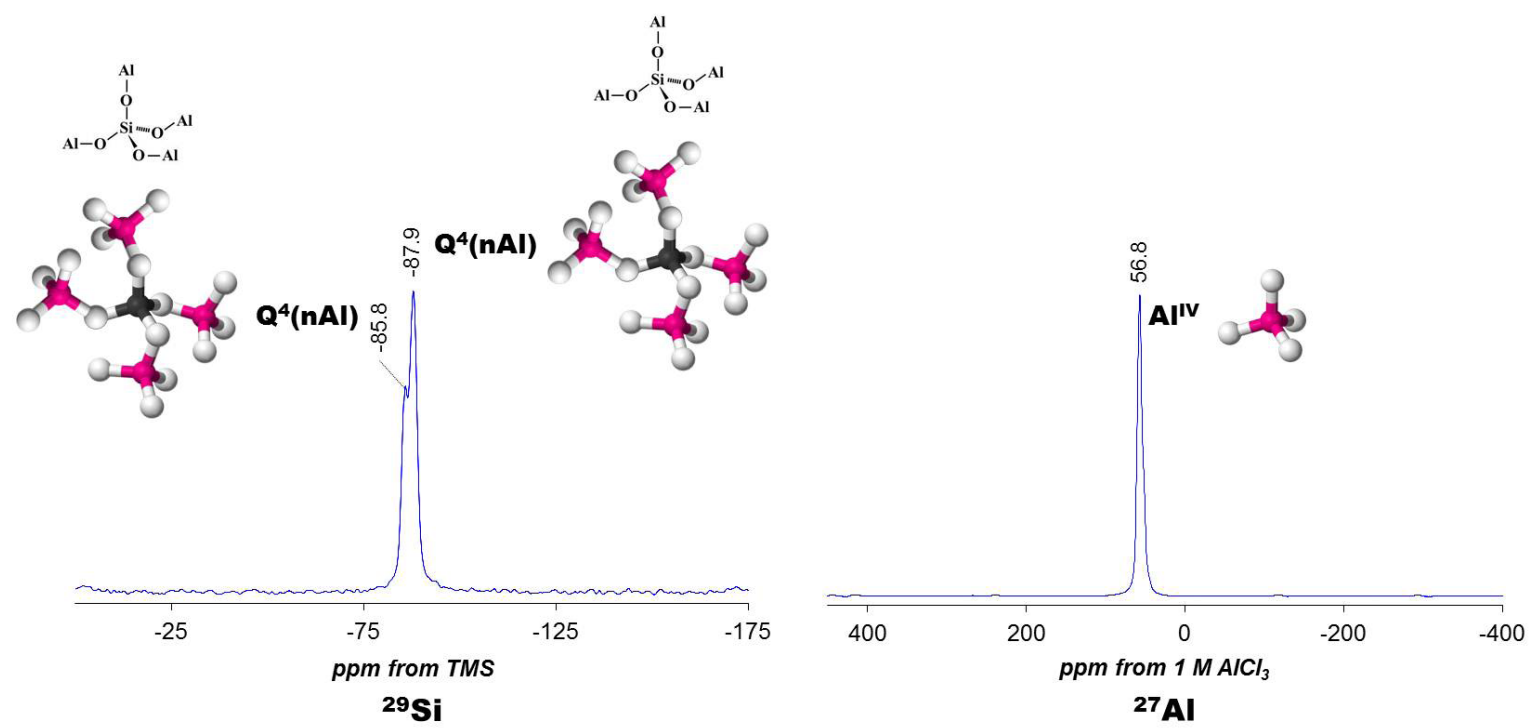

Fig. 7. ${ }^{29} \mathrm{Si}$ and ${ }^{27} \mathrm{Al}$ NMR spectra of the JBW-type structure obtained after treatment of kaolin in $3.99 \mathrm{M} \mathrm{NaOH}$ solutions at $200{ }^{\circ} \mathrm{C}$ after $168 \mathrm{~h}$.

\section{Conclusions}

The JBW-type framework with high crystallinity was successfully synthesized by hydrothermal treatment of raw kaolin as $\mathrm{SiO}_{2}$ and $\mathrm{Al}_{2} \mathrm{O}_{3}$ source, in $3.99 \mathrm{M}$ $\mathrm{NaOH}$ solutions at $200{ }^{\circ} \mathrm{C}$, during several reaction times. The role of a SDA in the reactant mixture was evaluated to estimate how it controls the formation of several zeotypes. SOD and CAN crystallized along with the JBW zeotype. The as-synthesized zeotypes were characterized by analytical techniques such as XRPD, SEM, FT-IR and MAS-NMR. The JBW zeotype crystallized in the orthorhombic space group $P n a 2_{1}$, with unit cell parameters $a=16.409(2) \AA$, $b=14.966(2) \AA$ and $c=5.2154(5) \AA$. SEM analysis revealed that zeotype crystals show a long prismatic lath-like shape with pseudohexagonal cross sections. FT-IR and MAS-NMR data allowed elucidating the structural groups and the ${ }^{29} \mathrm{Si}$ and ${ }^{27} \mathrm{Al}$ environments in the as-synthesized zeolites. In general, the analytical data were consistent with experimental and theoretical reports from the literature.

\section{ACKNOWLedgments}

The authors thank the Programme Alban (the European Union Programme of High Level Scholarships for Latin America), scholarship No. E05D060429CO, the Universidad Industrial de Santander and the University of Wolverhampton for providing financial support, source materials and research facilitates to C.A. Ríos during his doctoral fellowship. We highly appreciated Dr David Townrow, Mrs Barbara Hodson and Mrs Diane Spencer for their technical assistance in collecting XRPD, SEM and FT-IR data, respectively. We also thank Dr Apperley and the EPSRC solid state NMR Service of the University of Durham, for MASNMR data acquisition and interpretation.

\section{REFERENCES}

[1] T. Selvam, G.T.P. Mabande, M. Köstner, F. Scheffler, and W. Schwieger, "Hydrothermal transformation of porous glass beads into porous glass beads containing zeolite beta (BEA)," Stud. Surf.Sci. Catal., vol. 154, pp. 598-605, 2004. DOI: https://doi.org/10.1016/ S0167-2991(04)80857-7.

[2] L. Heller-Kallai, and I. Lapides, "Reactions of kaolinites and metakaolinites with $\mathrm{NaOH}$ comparison of different samples (Part 1)," Appl. 
Clay Sci., vol. 35 (1-2), pp. 99-107, Jan. 2007. DOI: https://doi.org/10.1016/j.clay.2006.06.006.

[3] C. A. Rios, C.D. Williams, and M.A. Fullen, "Nucleation and growth history of zeolite LTA synthesized from kaolinite by two different methods," Appl. Clay Sci., vol. 42 (3-4), pp. 446-454, Jan. 2009. DOI: https://doi.org/10.1016/j.clay.2008.05.006.

[4] Y. Zhao, B. Zhang, X. Zhang, J. Wang, J. Liu, and R. Chen, "Preparation of highly ordered cubic $\mathrm{NaA}$ zeolite from halloysite mineral for adsorption of ammonium ions," J. Hazard. Mater, vol. 178 (1-3), pp. 658-664, Jun. 2010. DOI: https://doi. org/10.1016/j.jhazmat.2010.01.136.

[5] E. Z. Hegazy, I. H. Abd El Maksod, and R. M. M. Abo El Enin, "Preparation and characterization of Ti and $\mathrm{V}$ modified analcime from local kaolin," Appl. Clay Sci., vol. 49 (3), pp. 149-155, Jul. 2010. DOI: https://doi.org/10.1016/j.clay.2010.04.019.

[6] M. M. Selim, and I.H.A.E. Maksod, "Hydrogenation of edible oil over zeolite prepared from local kaolin," Micropor. Mesopor. Mater., vol. 74 (1-3), pp. 79-85, Sep. 2004. DOI: https://doi.org/10.1016/j. micromeso.2004.06.011.

[7] A. M. Healey, P.F. Henry, G.M. Johnson, M.T. Weller, T.M. Webster, and A.J. Genge, "The synthesis and characterisation of JBW-type zeolites. Part B: Sodium/rubidium aluminogermanate, $\mathrm{Na}_{2} \mathrm{Rb}\left[\mathrm{Al}_{3} \mathrm{Ge}_{3} \mathrm{O}_{12}\right] \cdot \mathrm{H}_{2} \mathrm{O}$," Micropor. Mesopor. Mater., vol. 37 (1-2), pp. 165-174, May. 2000. DOI: https://doi.org/10.1016/S1387-1811(99)00263-2.

[8] A. M. Healey, G. M. Johnson, and M. T. Weller, "The synthesis and characterization of JBW-type zeolites. Part A: Sodium/potassium aluminosilicate, $\mathrm{Na}_{2} \mathrm{~K}\left[\mathrm{Al}_{3} \mathrm{Si}_{3} \mathrm{O}_{12}\right] \cdot 0.5 \mathrm{H}_{2} \mathrm{O}$," Micropor. Mesopor. Mater., vol. 37 (1-2), pp. 153-163, May. 2000. DOI: https://doi.org/10.1016/S1387-1811(99)00262-0.

[9] W.-J. Dong, W.-J. Li, K.-F. Yu, K. Krishna, L.-Z. Song, X.-F. Wang, Z.-C. Wang, M. O. Coppens, and S.-H. Feng, "Synthesis of silica nanotubes from kaolin clay," Chem. Commun., vol. 11, pp. 13021303, May. 2003. DOI: https://doi.org/10.1039/ b300335c.

[10] Ch.-F. Wang, J.-Sh. Li, L.-J. Wang, and X.-Y. Sun, "Influence of $\mathrm{NaOH}$ concentrations on synthesis of pure-form zeolite. A from fly ash using two-stage method," J. Hazard. Mater, vol. 155 (1-2), pp. 58-64, Jan. 2008. DOI: https://doi.org/10.1016/j. jhazmat.2007.11.028.

[11] C. Baerlocher, and L. McCusker. "Database of Zeolite Structures," 2013. Available on http://www. iza-structure.org/databases/.

[12] R. M. Barrer, and E.A.D. White, "The hydrothermal chemistry of silicates. Part II. Synthetic crystalline sodium aluminosilicates," J. Chem. Soc., vol. 2, pp. 1561-1571, 1952. DOI: https://doi.org/10.1039/ jr9520001561.
[13] S. Hansen, and L. Fälth, "X-ray study of the nepheline hydrate I structure," Zeolites, vol. 2 (3), pp. 162-166, Jul. 1982. DOI: https://doi.org/10.1016/S01442449(82)80046-8.

[14] D.-Ch. Lin, X.-W. Xu, F. Zuo, and Y.-C. Long, "Crystallization of JBW, CAN, SOD and ABW type zeolite from transformation of metakaolin," Micropor. Mesopor. Mater., vol. 70 (1-3), pp. 6370, May. 2004. DOI: https://doi.org/10.1016/j. micromeso.2004.03.003.

[15] C.A. Ríos. Synthesis of zeolites from geological materials and industrial wastes for potential application in environmental problems, Ph.D. Thesis. Wolverhampton, West Midlands: University of Wolverhampton, 2008.

[16] H. R. Mortaheb, A. Zolfaghari, B. Mokhtarani, M. H. Amini, and V. Mandanipour, "Study on removal of cadmium by hybrid liquid membrane process," J. Hazard. Mater., vol. 177(1-3), pp. 660 667, May. 2010. DOI: https://doi.org/10.1016/j. jhazmat.2009.12.082.

[17] S. Shimizu, and H. Hamada, "Synthesis of giant zeolite crystals by a bulk material dissolution technique," Micropor. Mesopor. Mater., vol. 48 (1-3), pp. 39-46, Nov. 2001. DOI: https://doi.org/10.1016/ S1387-1811(01)00328-6.

[18] A. Tripathi, and J.B. Parise, "Hydrothermal synthesis and structural characterization of the aluminogermanate analogues of JBW, montesommaite, analcime and paracelsian," Micropor. Mesopor. Mater, vol. 52 (2), pp. 65-78, Apr. 2002. DOI: https://doi.org/10.1016/S13871811(02)00270-6.

[19] C. A. Ríos, C. D. Williams, and M. J. Maple, "Synthesis of zeolites and zeotypes by hydrothermal transformation of kaolinite and metakaolinite," Bistua, vol. 5, pp. 15-26, 2007.

[20] B. Wei, Y. Wang, M.-H. Xin, and S.-L. Qiu, "Phenol solvothermal synthesis of JBW-type zeolites," Chem. Res. Chin. Univ., vol. 23 (5), pp. 511-513, Sep. 2007. DOI: https://doi.org/10.1016/S10059040(07)60111-1.

[21] M. T. Weller, "Where zeolites and oxides merge: semi-condensed tetrahedral frameworks," J. Chem. Soc., Dalton Trans., vol. 23, pp. 4227-4240, 2000. DOI: https://doi.org/10.1039/b003800h.

[22] A. Gil, M. A. Vicente, and L. M. Gandia, "Main factors controlling the texture of zirconia and alumina pillared clays," Micropor. Mesopor. Mater., vol. 34 (1), pp. 115-125, Jan. 2000. DOI: https://doi. org/10.1016/S1387-1811(99)00166-3.

[23] M. Hervieu, and B. Raveau, "A layer structure: The titanoniobate $\mathrm{CsTi}_{2} \mathrm{NbO}_{7}$," J. Solid State Chem., vol. 32 (2), pp. 161-165, Apr. 1980. DOI: https://doi. org/10.1016/0022-4596(80)90562-9. 
[24] V. Petricek, M. Dusek, and L. Palatinus. The crystallographic computing system, Institute of Physics, Czech Republic, 2006.

[25] E. Z. Hegazy, S. A. Kosa, I. Hamdy, and A. El Maksod, "Synthesis and characterization of JBW structure and its thermal transformation," J Solid State Chem., vol. 196, pp. 150-156, Dec. 2012. DOI: https://doi.org/10.1016/j.jssc.2012.06.014.

[26] A. D. Edgar, "A note on the lattice parameters of nepheline hydrate I," Am. Mineral., vol. 49, pp. 1139-1141, 1964.

[27] K. G. Ragimov, M. I. Chiragov, N. M. Mustafaev, and K. S. Mamedov, "Crystal structure of synthetic sodium-alumosilicate $\mathrm{Na}_{3} \mathrm{Al}_{3} \mathrm{Si}_{3} \mathrm{O}_{12} .2 \mathrm{H}_{2} \mathrm{O}$," Dokl. Akad Nauk URSS., Vol. 242, pp. 839-841, 1978.

[28] A. Aronne, S. Esposito, and P. Pernice, "FT-IR and DTA study of lanthanum aluminosilicates glasses," Mater. Chem. Phys., vol. 51 (2), pp. 163-168, Nov. 1997. DOI: https://doi.org/10.1016/S02540584(97)80287-8.

[29] A. Aronne, S. Esposito, C. Ferone, M. Pansini, and P. Pernice, "FT-IR study of the thermal transformation of barium-exchanged zeolite A to celsian," J. Mater. Chem., vol. 12 (10), pp. 3039-3045, Sep. 2002. DOI: https://doi.org/10.1039/b203859e.

[30] M. Park, C. L. Choi, W. T. Lim, M. C. Kim, J. Choi, and N. H. Heo, "Molten-salt method for the synthesis of zeolitic materials: I. Zeolite formation in alkaline molten-salt system," Micropor. Mesopor. Mater, vol. 37 (1-2), pp. 81-89, May. 2000. DOI: https://doi. org/10.1016/S1387-1811(99)00196-1.

[31] M. C. Barnes, J. Addai-Mensah, and A. R. Gerson, "The mechanism of the sodalite-to-cancrinite phase transformation in synthetic spent Bayer liquor," Micropor. Mesopor. Mater., vol. 31 (3), pp. 287-302, Nov. 1999. DOI: https://doi.org/10.1016/S13871811(99)00079-7.

[32] D. W. Breck, Zeolite Molecular Sieves: Structure, Chemistry and Use, 1st Ed., John Wiley, New York, 1974.

[33] C. Klein, and C. S. Hurlbut Jr., Manual of mineralogy: (after James D. Dana). 21st ed., rev. New York: J. Wiley, 1999.

[34] J. Pan, H. Zhang, and M. Pan, "Self-assembly of Nafion molecules onto silica nanoparticles formed in situ through sol-gel process," J. Colloid Interf. Sci., vol. 326 (1), pp. 55-60, Oct. 2008. DOI: https://doi. org/10.1016/j.jcis.2008.07.010.

[35] L. Mafra, J. A. Vidal-Moya, and T. Blasco. Annual Reports on NMR Spectroscopy, vol. 77, pp. 259-351, 2012. DOI: https://doi.org/10.1016/B978-0-12397020-6.00004-0.

[36] A. Cestari, L. Rodrigues-Avila, E. C. OliveiraNassor, P. F. dos Santos Pereira, P. S. Calefi, K. J. Ciuffi, S. H. Nakagaki, A. C. Pereira-Gomes, and E. J. Nassar, "Characterization of the CalciumFluoroaluminosilicate Glass Prepared by a NonHydrolytic Sol-Gel Route for Future Dental Application as Glass Ionomer Cement," Mat. Res., vol. 12(2), pp. 139-143, 2009. DOI: https://doi. org/10.1590/S1516-14392009000200005.

[37] The NMR Lab, Institute of Chemistry, Hebrew University, 2015. Available on: http://chem.ch.huji. ac.il/nmr/techniques/1d/row3/al.html. 
